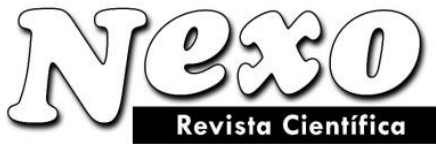

ISSN-E 1995-9516

Universidad Nacional de Ingeniería COPYRIGHT @ (UNI). TODOS LOS DERECHOS RESERVADOS

http://revistas.uni.edu.ni/index.php/Nexo

https://doi.org/10.5377/nexo.v34i04.12668

\title{
Applying of system models in the progress of formation and implementation of programs for innovative development of regions
}

\section{Aplicación de modelos de sistemas en el progreso de formación e implementación de programas para el desarrollo innovador de regiones}

\author{
Mafura Uandykova ${ }^{1}$, Diana Stepanova ${ }^{2, *}$, Svetlana Shchepetova $^{3}$, Leonid Ratkin ${ }^{4}$ \\ ${ }^{1}$ Narxoz Uniiversity. Almaty, Republic of Kazakhstan. \\ ${ }^{2}$ Plekhanov Russian University of Economics. Moscow, Russian Federation. \\ ${ }^{3}$ Financial University under the Government of the Russian Federation. Moscow, Russian Federation. \\ ${ }^{4}$ Scientific Research Institute for System Researching of Russian Academy of Sciences. Moscow, Russian \\ Federation. \\ *Corresponding author E-mail: $\underline{\text { d.i.stepanova@bk.ru }}$
}

(recibido/received: 21-mayo-2021; aceptado/accepted: 15-agosto-2021)

\begin{abstract}
The paper presents a model of the economic space for the innovative development of a region, based on the notation and principles of the modern theory of economic systems, which allows the transition process from the program-target method of management to the innovative development program-project management. Such a model is necessary to concretize the ways and stages of solving the problems of innovative development programs and the use of the modular concept of building a DSS, according to which the functionality of each module is based on a system of instrumental methods and models for data analysis, which make it possible to determine and formalize the goals of innovative development, directions growth, forecast and make optimal management decisions in the formation and implementation of the region innovative development program (F\&IRIDP). This approach makes it possible to identify imbalances in the regions development and eliminate the shortcomings of the used methods of programtargeted management of innovative development of the region (IDR) in the implementation of state programs, as well as concretize the required program indicators based on the proposed three-vector paradigm of innovative development. Also proposed a systemic dynamic economic-cybernetic model of a region with discrete variables.
\end{abstract}

Keywords: New theory of economic systems; System models; Innovative development; State program; Modeling; Regional development.

\section{RESUMEN}

El trabajo presenta un modelo del espacio económico para el desarrollo innovador de una región, basado en la notación y principios de la teoría moderna de sistemas económicos, que permite el proceso de transición del método de gestión programa-objetivo al programa de desarrollo innovador. gestión de 
proyectos. Dicho modelo es necesario para concretar las formas y etapas de resolución de los problemas de los programas de desarrollo innovadores y el uso del concepto modular de construcción de un DSS, según el cual la funcionalidad de cada módulo se basa en un sistema de métodos y modelos instrumentales para análisis de datos, que permitan determinar y formalizar las metas de desarrollo innovador, direccionar el crecimiento, pronosticar y tomar decisiones de manejo óptimas en la formación e implementación del programa de desarrollo innovador de la región ( $F$ \& IRIDP). Este enfoque permite identificar los desequilibrios en el desarrollo de las regiones y eliminar las deficiencias de los métodos utilizados de gestión programática del desarrollo innovador de la región (IDR) en la implementación de los programas estatales, así como concretar los indicadores programáticos requeridos basados en sobre el paradigma propuesto de tres vectores de desarrollo innovador. También propuso un modelo económico-cibernético dinámico sistémico de una región con variables discretas.

Palabras claves: Nueva teoría de los sistemas económicos; Modelos de sistema; Desarrollo innovador; Programa estatal; Modelado; Desarrollo regional.

\section{INTRODUCTION}

Strengthening the necessity of transition process to an innovative model of the economy, as a condition for increasing economic growth rates to improve and increase the welfare of the population, is obvious. This, in a natural way, is connected both with the existing experience of modern social and economic life of developed countries, leading the ratings of the GCI and GII, and with the ever increasing competition (developed countries are intensively and systematically conquering the markets of developing countries with products of high quality and technological level), due to which is becoming more difficult to enter such markets with their products, which affects both the standard of living and the economy of developing countries (post-Soviet space).

The presented research examines problematic issues on the development of mechanisms that stimulate innovation in the regions on the basis of system modeling of the F\&IRIDP. The implementation of such an approach requires a transition to program and project management based on a new theory of economic systems, consideration and development of system models of the F\&IRIDP processes. The transition to program and project management requires considering the complex of projects as the main activities and defining and setting the main criteria for innovative development, with the possibility of assessing them and, most importantly, consistent with the main indicators of the socio-economic development of regions, as well as with the indicators of global ratings. The solution of such problems is associated with serious difficulties that require structural changes on a regional scale, as interconnected economic entities (Porter, 2000; Rycroft and Kash, 2002; Rothwell, 1994; Tödtling and Trippl, 2005; Padmore, 1998). The implementation of such changes also requires a preliminary study and assessment of the proposed measures, the expected possible consequences and risks, that is why it is necessary to create and use effective tools for analyzing complex large systems and choosing development paths. To solve this problem, methods and tools of system analysis are involved: system modeling, project and scenario management, etc.

\section{LITERATURE REVIEW}

System modeling of F\&IRIDP processes is important for analyzing the essence of the tasks being solved, the influence of mutual relations on the overall effectiveness of decisions made, as a necessary scientific analytical approach in promoting regional development and developing a general model of regional economic growth.

System modeling of complex objects takes into account all existing direct, reverse, cross-links, while control is implemented through information and communication processes and connections of the contour, covering all other contours. Management of regional development, including innovation, provides for the existence of 
objects and subjects of management, while the developed models also include management of the formation of conditions for activity.

Many research and works play the important role in control theory (Leontiev, 1997; Granberg, 1989, 2003; Morris, 1971; Makarov and Bakhtizin, 2013; Kleiner, 2007, 2015; Kleiner et al., 2019).

So, Granberg (1989) in their research for the first time considered the modeling of the economic system through system modeling, defining it as multi-level and multidimensional, where subsystems are represented by special mathematical models, emphasized the importance of building regional typologies, regional situational analysis, developing forecasts, simulating the consequences of socio-economic enterprises at the level of the economic complex of the country and its regions, the choice of financial and economic structures, etc. (Kleiner, 2011). Thus, to date, system modeling is widely used in solving management problems as a methodological approach to formalize the goals and criteria of management, to study the mechanisms of functioning of system objects.

Analysis of the research of Russian and foreign scientists on the problems of region innovative development (RID) made it possible to draw a conclusion about the established approaches to the management of RID, as well as conclusions about the institutional component for the formation of an appropriate innovation policy, support (including state), regulation of innovative processes (Alekseev, 2009; Bakhtizin and Akinfeeva, 2010; Doloreux and Parto, 2005; Kitsios and Kamariotou, 2018; Krugman, 1994; Kuznetsov, 2008; Lau and Lo, 2015; McGregor and Pouw, 2017; Medvedev, 2016; Mensch, 2006; Minaev et al, 2008; Polukeeva, 2014; Wahyudin and Hasibuan, 2015; Webster, 2002; Verganti, 2008; Polenske, 2007; Shash, 2014).

Speaking about institutional support, it can be noted that this is a rather effective approach, since the environment (socio-economic, political, legal) forms the basis for innovative development. For example, in the countries leading the GCI ranking, appropriate support plans have been developed and are being implemented that contribute to innovative development and the corresponding result in the GCI ranking: USA (Innovation Partnership Program), France (Innovation Plan), England (Science and Innovation strategy).

As for Russia and Kazakhstan, despite similar efforts to create conditions conducive to the implementation of innovative development plans: various government programs, funds, scientific and technical information bodies, resolutions, financing programs, etc., the transition to an innovative development path is facing serious problems. A comparative analysis of the ranking of countries by the GCI, according to the World Bank, shows that Russia in 2017 compared to 2016 rose by five positions - from 43 to 38 places, and Kazakhstan worsened its indicators by 15 positions in comparison from 2015, and on 4 positions - from 2016, taking 57th place with a total score of 4.3. In 2019, Kazakhstan took 55th place in the ranking, while in 2015 it was ranked 42nd; Russia is on the 43rd line, the same as in 2018.

The development of any country is carried out in accordance with strategic and program documents plans that and are the main tool for managing the development of the country, its regions, constituent industries, which include a number of government development programs aimed at raising the level of the national economy, including a system of targets and benchmarks.

Currently, the basis for managing the development of the economies of most countries at all levels has become a technology based on a program-based target approach, which, in its general description, is based on the chain of "goals - directions - methods / measures - means / resources", which has proven itself well in the post-Soviet states, as well as in developed countries, leading the GCI ratings.

The number of countries with a national development plan has now more than doubled, from 62 in 2006 to 134 in 2018. More than 80 percent of the world's population currently lives in countries with a national 
development plan of one form or another. One of the factors that gave impetus and contributed to this process is partly the need to plan for the Sustainable Development Goals (United Nations, 2015; OECD, 2019).

The result of the implemented programs in program-target planning and management are qualitative indicatorsconsequences, but not a specific result.

The existing shortcomings of program-targeted management, implemented on the basis of the process approach, in total with dynamic changes in the external and internal environment of economic systems, give an understanding the necessity of a transition process to flexible adaptive management and substantiate the necessity for a transition to project management, which is already understood and accepted at the level of the higher management structures of the post-Soviet countries, an example of this is the development of national and federal existing projects and similar documents from other countries.

Measures taken to improve the effectiveness of programs, such as the introduction of performance-based budgeting mechanisms, can be rightly interpreted as a set of policy measures aimed at improving the efficiency of the public sector as a whole (President of the Russian Federation, 2018). However, a complete transition to project management in the post-Soviet space has not yet taken place, the state programs themselves are being implemented on the basis of a process approach, and the announced national and federal projects do not have the full characteristics of projects. The study showed that, in general, they remained at the level of program-target documents, due to the lack of a systemic complex interconnection with the general goals of innovative development, the lack of precise, mathematically justified goals and management criteria, formalization of project management processes, including problems with the assessment of results and possible risks, and, in general, the remaining stages of the formation and analysis of projects.

\section{METHODOLOGY AND MODELS}

An analysis of the interrelationships between government documents shows that, in fact, strategic and program documents are an indication of the ways, directions and stages of achieving the set development goal (at least descriptively) - where, how and to what result you need to go-goal-setting, they are plans, at first glance, remove conceptual uncertainty and allow for long-term socio-economic development.

It should be noted that not only the complex of programs for the development of the country, regions and industries is presented systematically. The region, just as an object is a system, with program-targeted management, and as a system has goals, objectives, ways (activities) and means (resources) of implementation, its development program, we can represent in the form of a complex of projects that complement the system of program-targeted documents, which, in turn, may have, on the one hand, a system of restrictions, , on the other hand, form a system, and as a system have a focus on the result. However, this gives us only the opportunity to consider the programs themselves and the processes initiated by them as an economic system, while conceptual uncertainty and other problems indicated in the shortcomings of program-target management are still not removed.

The solution to such a problem is possible only when solving the following tasks through system analytics to project management:

1. Conducting economic and mathematical, including economic and cybernetic systems analytics. The concept of system analysis and development modeling provides for taking into account the relationship between subsystems from the standpoint of integrity, that is, the assessment and the most likely reaction of managed objects to the actions of the remaining individual components of the regional system and the impact on the final result and future development conditions. Such an approach is very important, since in relation to regional development it presupposes, first of all, the study of the causes, driving forces, areas of permissible and implemented actions, explicitly or by their consequences for any of its constituent subsystems. Therefore, it is necessary to investigate the various components of regional and sectoral systems with existing links and the 
relationship of these components and systems, to identify and compare options for action in order to make a decision in favor of those that, when achieving any goal, will not harm other goals. For a systematic analysis of regional development, the following is necessary: to express in the form of a mathematical criterion the motives that guide the behavior of subsystems and to outline a number of its alternatives as the area of the corresponding objective function, to give a qualitative and quantitative definition of the patterns of their reactions and possible boundaries of reactions.

2. System modeling involves evaluating goals and means - resources. Criteria are needed for the selection of goals to be achieved at the upper level and the optimal means of achieving them - goals of the lower levels. That is, in complex systems there is always a hierarchy of goals. For the F\&IRIDP programs, a system of integrated (comprehensive) assessment of the innovative potential of the region, assessment of development options for programs is needed, which makes it possible to manage the assessment of the state to the required indicator in accordance with the goals, objectives and resources set by the development program.

3. Since the implementation of programs is accompanied by certain objective conditions of the external environment in which their implementation takes place, there is always the possibility that for one reason or another it will not be able to achieve its goal, i.e., it is accompanied by risks. In this regard, it is necessary to assess the risks and determine measures to eliminate or mitigate them. Also, objective conditions may require adjustment of development programs, all this, in turn, requires continuous monitoring and analysis of implementation and, if necessary, taking appropriate measures.

4. Within the framework of systemic modeling, an appropriate system of criteria for assessing the effectiveness of innovative development management both at the macro and meso levels is important, with the possibility of timely adaptation to a dynamically changing economic situation, which requires the development and use of such an innovative lever in the form of resource multipliers and their assessment based on systemic interaction of all resources.

Figure 1 shows a conceptual model of program and project management of the region, based on the project management methodology.

This includes blocks such as:

1. Selection of an innovative development program with many projects for further evaluation in order to form multiprograms in development areas.

2. Selection of criteria for evaluating projects in accordance with the goals of state programs, agreement of goals.

3. Evaluation of projects using the tools of the project approach with the calculation of all indicators of project efficiency. The use of an integrated (comprehensive) assessment of the innovative potential of the region, assessment of development options for programs, which makes it possible to manage the assessment of the state to the required indicator in accordance with the goals, objectives and resources set by the development program (optimization task).

4. Formation of a program of innovative development taking into account risks, determination of a complex of multi-projects in areas (programs) by holders of each project; determination of financing options (with equity participation of holders for programs of one direction or financing of a single project by the program holder); this takes into account the accounting of high, medium and low risk projects (optimization task). 
5. Scenario analysis of the program development options based on the calculations, processing and analysis of the results. In case of dissatisfaction with the development results, return to the blocks 2, 3, 4 and further decision-making on the recommendation of the program for implementation.

6. The process of program implementation, support and necessary adjustments, if necessary, redistribution of resources, calendar time, financial costs, which suggest the solution of optimization problems. Here, if necessary, you can envisage a return to the blocks 5, 6.

7. Analysis of the results. Checking the compliance of the results obtained with the comprehensive assessment of the development of the region, if necessary, to improve the assessment to the required one. Thus, the optimization problem is solved.

\section{Program completion.}

Project management has a number of features that distinguish it from program-target management, it is aimed at a specific result, with the ability to assess the degree of personal contribution of each project participant, the effectiveness of the work performed, and optimization of management processes and interaction between all project participants. The concept of the formation of programs-projects for the implementation of development programs allows achieving integrated management and implementation of the entire set of strategic and target programs based on system modeling of development programs, representing an innovative mechanism for managing the economy of industries and regions. This methodology is also acceptable from the point of view of technical implementation. It is important to revise the very procedure for the formation of strategic and program-targeted documents, reorienting them to the program-project approach of formation. The presented model does not include this block: a mathematical description of the development trajectory based on the economic and cybernetic model of the region's innovative development. 


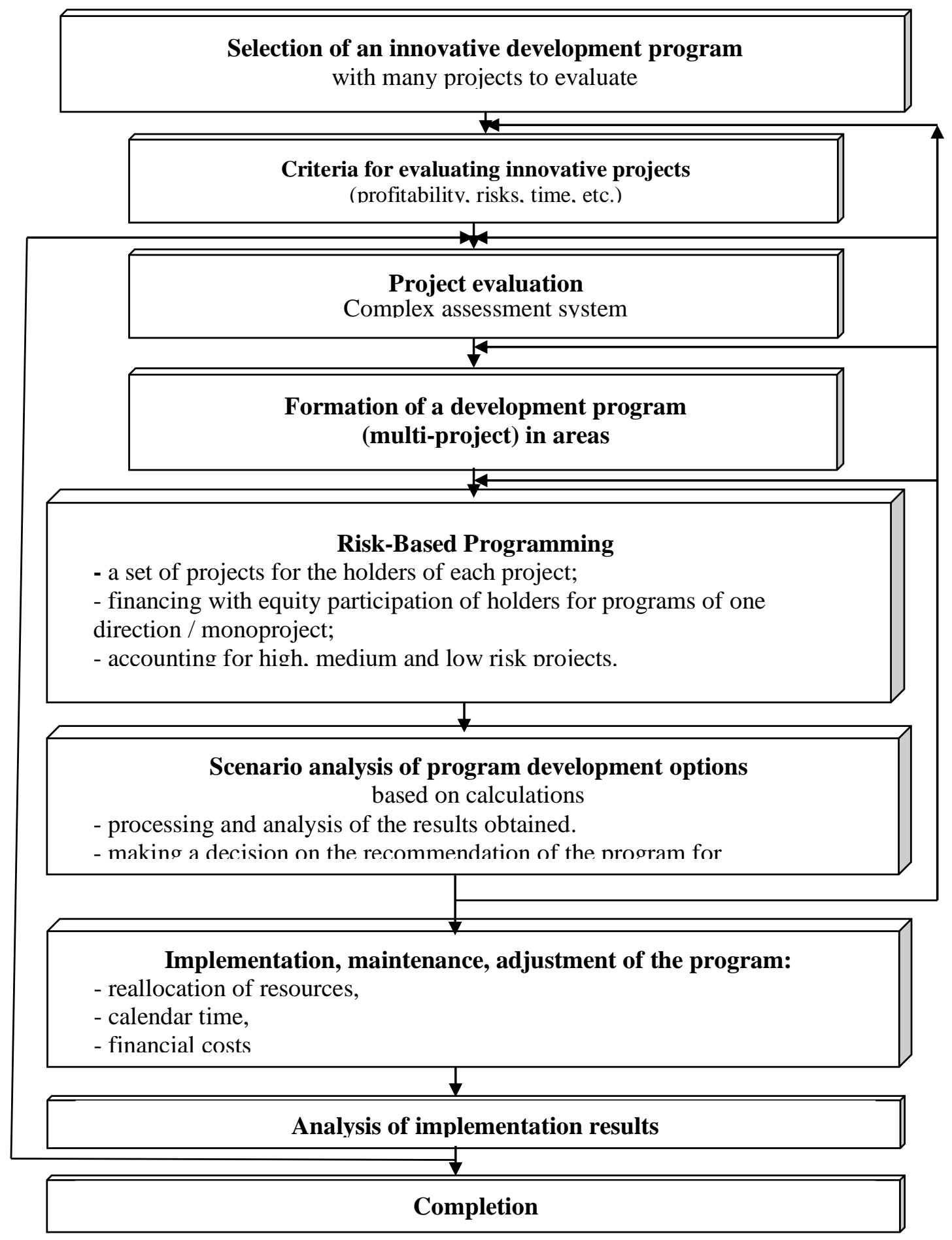

Figure 1. Conceptual model of program and project management of regional development Source: authors

We will start from the conclusion about the need to consolidate the economy, search for indicators that reflect macroeconomic indicators through mesoeconomic indicators, characterizing at the same time economic growth and requiring the construction of an integral economy and systemic models for its study. 
The economic system of the country is a complex dynamic system, here it is important to formalize the goals and management criteria that allow and determine their achievement. In complex systems, direct intervention is unacceptable, since it can lead to unpredictable consequences through the mismatch of its constituent subsystems, through a multitude of cross-links.

To implement such a task, it is important to build a cybernetic model based on a systemic consideration of all interrelationships, which includes all systems and subsystems developing in the space of the economic system. When modeling economic systems, it is necessary to take into account all information, financial, material flows, taking into account their reactions to managerial influences (Yang, Pita and Singh, 2013; Porter, 2002).

The structure of systems obeys a hierarchical principle and corresponds to a complex dynamic system. The cybernetic model shown in Figure 2 and consists of three groups of systems: analysis and synthesis systems (labor productivity system, finance and price system, economic information system), executive economic systems (systems of material production and services, population and labor resources system, system science and technology, the system of interregional, international economic relations) and resulting systems (systems of aggregate social product and national income, system of national wealth, system of public welfare) (Manescu, 1986; Zviran, 1990).

Proposed in the works of scientists (Makarov and Bakhtizin, 2013; Kleiner, 2007, 2011, 2015; Kleiner et al., 2019) the mesoeconomic approach for the study of regional economies, the conclusion about the need to consolidate the economy, the search for indicators reflecting macroeconomic indicators through mesoeconomic indicators, which characterizes economic growth, requires the construction of an integral economy, that is, a multilevel systemic approach to its consideration, therefore, and system models for its study. Only a systematic approach, purposefully focused on the search for organic harmony, gives the key to the correct organization of relationships.

Using the considered by Kleiner (2007) variable characteristics of the economy with respect to the homogeneity of economic space and time, we can present similar quantitative and qualitative characteristics to set the degree of harmony for an innovative economic system (innovative development), taking into account the inherent dynamism of innovation processes.

Variable characteristics of space and time affect innovation processes and their development. Makarov (2013) and others note that regional innovations depend on the size of the innovation space, which manifests itself through all the potential relationships between the structural components of the economy and their innovative activities, being organizational, technological, financial, socio-political and other resource for innovation. The effectiveness of the innovative development of the regions depends on how effectively the innovation space and the resources provided to it are used. In this regard, it is important to determine the structural components themselves, their systemic relationship, which have a significant impact on the levels of variable characteristics.

We will considering in our work socio-economic processes, programs and projects as economic systems for G.B. Kleiner (2011). In systemic modeling of F\&IRIDP we will be based on the new theory of economic systems (NTES) (Makarov and Bakhtizin, 2013), according to which "the basic functional properties of socioeconomic systems are determined by their morphological characteristics, which include: the presence of certain boundaries in space (spatial localization) and (or) in time (temporal localization)" (Kleiner, 2015, p. 9). On the basis of NTES, we have the same four types of systems for the innovative economy (IE): objects (IOb) enterprises of the industries of the region that implement the processes of production and consumption of innovative products, the environment (IEn) - the system of resources of the region, processes (IPr), the very complex of measures of the innovative development program, due to which the states of objects and / or the environment change; projects (IP) - a system that generates ideas that are reflected in the form of a complex of projects. This is an important conclusion that we will use in the future. Turning again to the space-time 
continuum for the named four classes, we have four disjoint subsets of fundamentally different types of systems of the innovative economy (Figure 2).

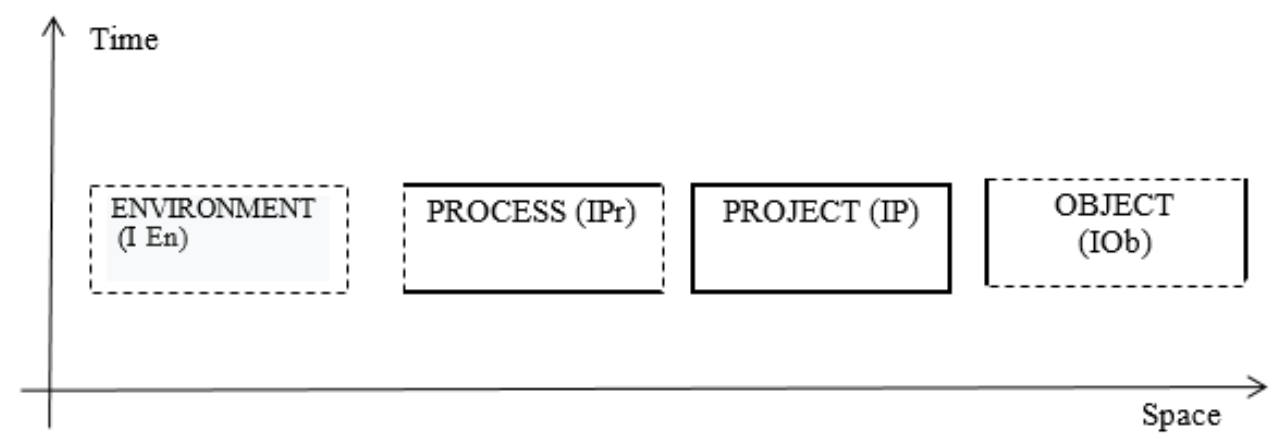

Figure 2. Representation of types of systems in the space-time continuum Source: authors

Further, according to the NTES, the basis of the systemic structure of the country's economy is also made up of 4 subsystems: "the state as a political organization regulating all aspects of the country's socio-economic development; society as a structured population of the country with the help of various public organizations; economy as a sphere of production, consumption, distribution and exchange processes; business as a system that accumulates capital and invests in various projects in order to generate profit ", which are reflected (projected) to subsequent levels. Based on these prerequisites, the study of the innovative development of the region can be viewed from the perspective of a four-helix model that allows to link innovations in all areas and show their mutual influence. Since the region is a subject of the meso-level, we can also structurally represent the configuration of the named subsystems: "regional power that regulates all aspects of the socio-economic development of the region; regional society, as the population of the region structured with the help of various public organizations; regional economy as a sphere of production, consumption, distribution and exchange processes; and regional business, as a system that accumulates capital and invests in various projects in order to make a profit " (Kleiner, 2011, p. 205), i.e. we have in "governance - society - economy - business".

Proceeding from the NTES, the research of the RID can be viewed from the perspective of a four-helix model that allows to link innovations in all areas and show their mutual influence through regional "governance society - economy - business". The purpose of the study of systemic cybernetic models, the connections between them and the processes occurring in them is to order the phenomena in specific economic spatial and temporal conditions.

In the logical structure of the cybernetic model, the above-mentioned subsystems are represented by separate blocks (synthesis subsystems, executive and resulting), which make it possible to comprehensively interconnect all the links of the economic space of the region, based on the transition to a systemic model of the economy and modeling the processes of forming and implementing programs. Following the presented four subsystems, we will single out the corresponding subsystems in the cybernetic model of the system for managing the innovative development of the region, presented in Figure 3 as a logical structure of interconnections between the blocks of the regional economic system. 


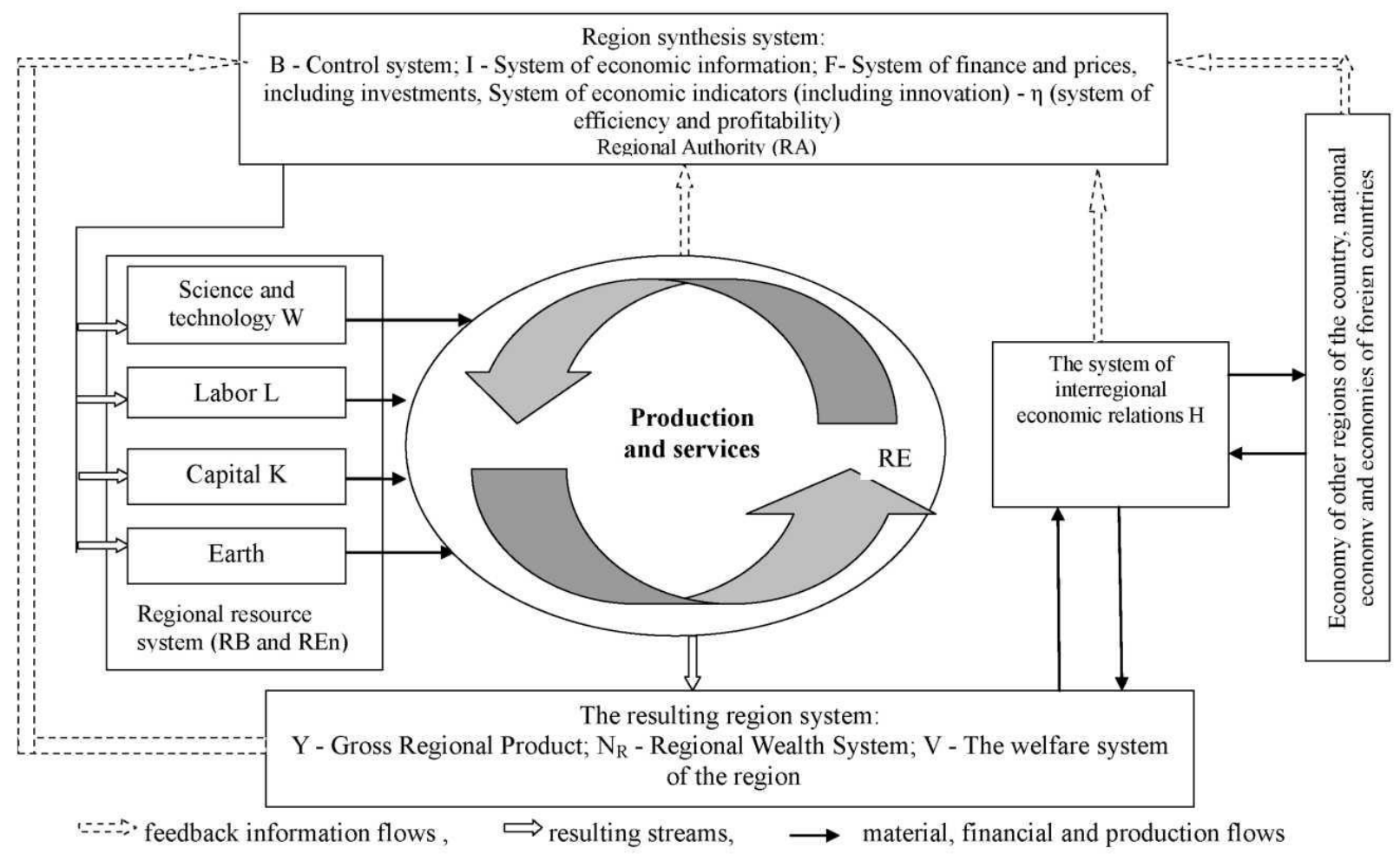

Source: compiled by the authors.

Figure 3. The logical structure of the interconnections of the blocks of the economic system of the region Source: authors

The result of the action of the regional power subsystem is a synthesis system that includes a management system B, all information resources I, a system of efficiency and profitability $\eta$, labor productivity A, finance and prices F. The functions of the subsystems of the regional economy, society and business are implemented through the executive system, which includes: labor L, system of science and technology W, capital or system of material production and services $\mathrm{K}$, interregional economic ties $\mathrm{H}$; and the resulting system: gross regional product $\mathrm{Y}$; the regional wealth system $\mathrm{N}_{\mathrm{R}}$ and the welfare system of region $\mathrm{V}$.

Then the model of the socio-economic system of the $\mathrm{G}_{\mathrm{R}}$ region looks like the formula (1):

$$
G_{R}=\left\{L, I, \eta, A, F, B, W, K, H, N_{R}, V, Y\right\}
$$

The subject composition of the economy and its structure are presented according to the NTES in the form of a multi-level multi-subject system, which includes the state at the macro level, regions and industries at the meso level, enterprises at the micro level, and individuals at the nano level. Projecting the subject composition of the economy onto the economic system taken in the work, ie, onto the socio-economic processes, programs and projects, we have the following composition of the economic system: macro level: state strategic programs; meso-level: regional, sectoral, target, departmental and micro-level (programs of enterprises, organizations, etc.).

As an object of management, the state program of innovative development is a complex set of activities and processes, in which the processes are interconnected functionally, in terms of timing, performers and resources. To organize the implementation of programs, a single leadership is needed, centralized in terms of planning, financing, monitoring, coordination, and legal support. Formation process and implementation requires the consolidation of efforts of all subsystems, starting from the Government of the country, regional 
administrations and departments, infrastructure, scientific, financial organizations, industrial enterprises. To do this, it is necessary to use the transition from program-targeted management to program-project management and system management of a complex of strategic and planned development programs for the country and its regions, which are an integral system of interrelated documents.

Now, when innovative development is presented through a systemic consideration in space and time, the cybernetic model of management of an innovative economy for systemic modeling of the direction of optimal growth can be represented as a dynamic model with discrete variables, the state vector of which gives the position of the system in space at any time.

The state vector $\mathrm{z}_{\mathrm{t}}$ of the management model contains data on the population of the region $\mathrm{L}$, wealth, the achieved level of national well-being, labor productivity A, efficiency and profitability $\eta$, the volume of material production $\mathrm{K}$, the state of scientific research, reflected in the indicators of technological development $\mathrm{W}$, on interregional and international economic relations $\mathrm{H}$. From formula (1) we have that $\mathrm{z}_{\mathbf{t}}$ has the following form (2):

$$
\mathrm{z}_{\mathrm{t}}=\{\mathrm{I}, \mathrm{L}, \eta, \mathrm{A}, \mathrm{F}, \mathrm{W}, \mathrm{K}, \mathrm{H}\}
$$

Through $\mathbf{u}_{\mathbf{t}}$ denotes the vector of management in the three above-mentioned areas of innovative development and reflects the state of the synthesis system B at time $t$, decisions concerning the size of the consumption fund, the volume of capital investments in the system of material production and services associated with projects of innovative development programs, and also in the non-production sphere, the volume and structure of exports, imports, etc. and has the form (3):

$$
u_{t}=B_{t}=\{I, \eta, A, F\}
$$

The input vector $\mathbf{x}_{\mathbf{t}}$ contains information about the necessary material and financial resources of projects of innovative programs, the demand of the population, etc. Thus, in general, we have the following cybernetic system model for managing innovative development (4):

$$
\mathrm{z}_{\mathrm{t}+1}=\mathrm{G}_{\mathrm{t}}\left(\mathrm{z}_{\mathrm{t}}, \mathrm{u}_{\mathrm{t}}, \mathrm{x}_{\mathrm{t}}\right)
$$

The area of admissible control actions $\mathrm{U}$ is the product of the sets $\mathrm{U}_{\mathrm{i}}$ for each $\mathrm{i}$-th component of the control vector (5):

$$
U=\prod_{\mathrm{i}=1}^{\mathrm{k}} \mathrm{U}_{\mathrm{i}}
$$

The systemic management model (2) is supplemented by restrictions on the ways of using the region's resources. The model constraint system is as follows (6):

$$
\sum_{t=0}^{T} Q_{t}\left(z_{t}, u_{t}, x_{t}\right)=\varphi
$$

where,

$\mathrm{T}$ - boundaries of the period of consideration,

$\varphi$ - a vector determined by resource constraints of development programs. 
Regions of growth and management are determined depending on the set of possible management decisions, constraints, management structure, dynamics and using forecasting methods. We define innovative development as the growth rate, i.e., an increase in the gross regional product, in these conditions, the management system is aimed at expanding the growth zone of $\mathrm{P}_{\mathrm{t}}$. In defining this zone, the regional / sectoral level governing body takes into account the need to increase regional wealth. and increase on this basis the level of well-being of the population. Control of the development of the system in the "growth zone" is carried out using the vector of output values of the component of the vector yt, this includes the value and structure of regional income $\mathrm{Y}$, elements of regional wealth $\mathrm{N}_{\mathrm{R}}$, as well as indicators reflecting the well-being of the population $\mathrm{V}$, determined by the levels of labor productivity and economic efficiency of production, the volume and efficiency of foreign trade, etc.

The development of the presented model of system development in the established growth zone $\mathrm{P}_{\mathrm{t}}$ is described by the expression (7):

$$
y_{t}=\lambda_{t}\left(z_{t}, u_{t}, x_{t}\right)
$$

Thus, the cybernetic system control model consists of the following 3 equations (8), (9), (10). Growth equation (8):

$$
\mathrm{z}_{\mathrm{t}+1}=\mathrm{G}_{\mathrm{t}}\left(\mathrm{z}_{\mathrm{t}}, \mathrm{u}_{\mathrm{t}}, \mathrm{x}_{\mathrm{t}}\right)
$$

Limitations (9):

$$
\sum_{t=0}^{T} Q_{t}\left(z_{t}, u_{t}, x_{t}\right)=\varphi
$$

Output quantities (10):

$$
\mathrm{y}_{\mathrm{t}}=\lambda_{\mathrm{t}}\left(\mathrm{z}_{\mathrm{t}}, \mathrm{u}_{\mathrm{t}}, \mathrm{x}_{\mathrm{t}}\right)
$$

A difficult task is the preparation of the data necessary for the calculations, charged with the responsibility of the economic information system. The development trajectory in this model is determined in the course of optimizing the tasks of program and project management (megaproject, including multi- and monoprojects) within the three-component vector of development directions that ensure optimal growth of the economic system.

In order to optimize the economic and cybernetic model, various values of the objective function and scenarios of the direction of development (growth) are considered to select the most appropriate options for achieving the intended goal. The development trajectory functions that allow achieving an increase in gross regional product (GRP) have the following general form (11):

$$
\max Y(z, u)=\max \sum_{t=0}^{T} \beta_{t}\left(z_{t}, u_{t}, x_{t}\right)
$$

Thus, the cybernetic model of managing the innovative development of the region (1) is transformed into a systemic model of dynamic optimization.

Based on the application of the cybernetic model and development control algorithms, the system model supports the optimal control mode (12): 


$$
\overline{\mathrm{u}}=\alpha\left(\mathrm{z}_{\mathrm{t}}, \mathrm{z}_{\mathrm{t}-1}, \ldots, \mathrm{z}_{\mathrm{t}-\mathrm{k}}, \mathrm{x}_{\mathrm{t}}, \mathrm{x}_{\mathrm{t}-1}, \ldots, \mathrm{x}_{\mathrm{t}-\mathrm{k}}\right)
$$

A specific method for finding the optimal solution in the control process is explained by the control algorithm.

The trajectory of optimal, balanced and proportional growth is characterized by dependencies (13) and (14):

$$
\begin{aligned}
& \mathrm{z}_{\mathrm{t}+1}=\mathrm{G}_{\mathrm{t}}\left(\overline{\mathrm{z}}_{\mathrm{t}}, \alpha_{\mathrm{t}}(\overline{\mathrm{z}}, \mathrm{x}), \mathrm{x}_{\mathrm{t}}\right) \\
& \mathrm{y}_{\mathrm{t}+1}=\lambda_{\mathrm{t}}\left(\overline{\mathrm{z}}_{\mathrm{t}}, \alpha_{\mathrm{t}}(\mathrm{z}, \mathrm{x}), \mathrm{x}_{\mathrm{t}}\right)
\end{aligned}
$$

\section{MODEL DISCUSSION AND APPLICATION}

We detail the economic space of innovative development of regions based on the representation of the above described in the form of four types of systems - Figure 4.

For an innovative economy (IE): objects $(\mathrm{IOb})$ - enterprises of the branches of the region that implement the processes of production and consumption of innovative products, the environment (IEn) - the system of resources of the region, including natural, labor, forming a subsystem of creative potential, as well as a subsystem of legislative acts that form an innovation policy, in which objects interact and innovative processes, processes (IPr), the very complex of measures of the innovative development program, due to which there is a change in the state of objects and / or the environment; projects (IP), a system that generates ideas that are reflected in the form of a complex of projects (megaproject, for the implementation of the state program of innovative development of regions, industries, which includes multiprojects and monoprojects; multiprojects consisting of monoprojects, i.e., individual projects combined for the solution / implementation of one big task), due to which there is a change in the state or position of the economic systems themselves, that is, design systems underlie the change in systems. At the same time, development programs are disclosed through a set of projects.

Innovative development requires a coordinated, consistent, "nationwide" approach to innovations, which should be developed in three main groups of areas: technological, monetary and financial, socio-political (innovation in development management). The emphasis here is on the fact that technological innovation is not sufficient for economic growth, therefore, is not decisive for an innovative economy, given that it is important to create a common basis for an innovative economy, and here also monetary, financial and management innovation groups are needed, however, their development lags far behind the first group. So, in this work, we consider innovative development through the growth rates achieved through innovation, in three equal areas of the economy of the country and its territories. 


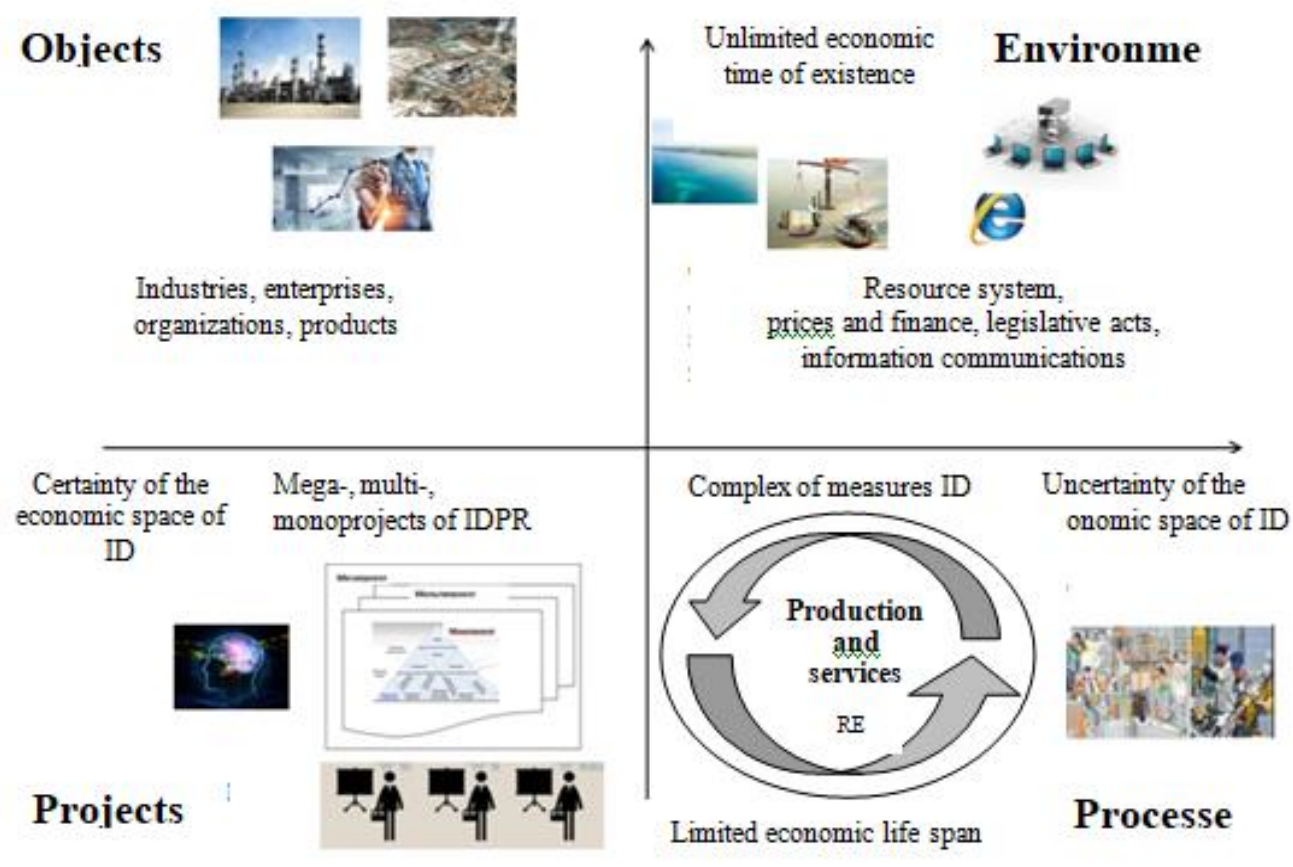

Figure 4. Economic space for innovative development of regions Source: authors

Thus, projects are immersed in the space of a three-component vector of innovative development of regions in three equal directions: in the real sector - technological innovation, in the financial sector - monetary and financial and in the socio-political sector - management innovations. Figure 5 shows the directions of innovative development of regions in the economic space in which projects of development programs are being implemented.

A clear understanding of the relationship between the directions of development and the mechanism for integrating individual innovation processes into holistic direction of development appears. Possibility of analyzing the influence of the nature of structural changes with the necessary completeness, determining effective management mechanisms over innovations in the development of the country and its regions. This approach is based on systemic and dynamic development, taking into account the strategic focus and full coordination of development. 


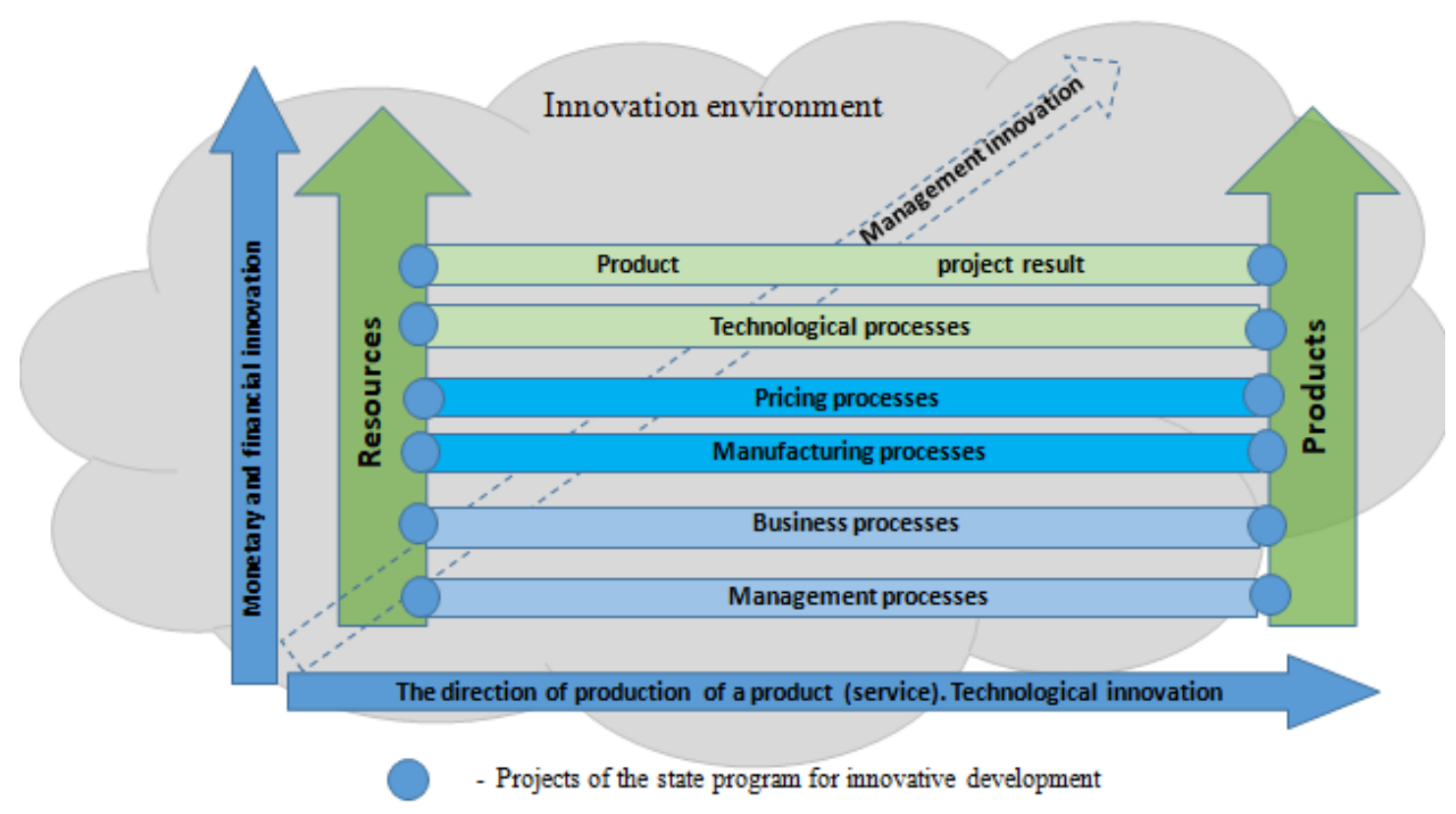

Figure 5. Directions of innovative development of regions in the economic space Source: authors

\section{Building a decision support system based on system models of F\&IRIDP processes}

Based on the conceptual model of program and project management of regions - Figure 1, based on the methodology of project management, considering the decision support system for the implementation of the state program of innovative development of regions. As noted above, the efficiency of the work performed, optimization of management processes and interaction between all project participants.

The main stages of the life cycle of analytical system modeling of regional development are shown in Figure 6. It consists of the blocks:

- databases of the state of socio-economic development of regions, projects, their assessments, formed strategies (projects-programs), intermediate and final values of indicators, a library of models for the formation of programs;

- analysis of the socio-economic situation, definition of goals, selection of efficiency criteria, formation of growth directions;

- development of models for the formation of regional development programs on the basis of program and project management;

- analysis and evaluation of indicators of the implementation of many programs-projects for the development of the region according to the developed models;

- adjustments to regional development models based on quantitative and qualitative indicators. 


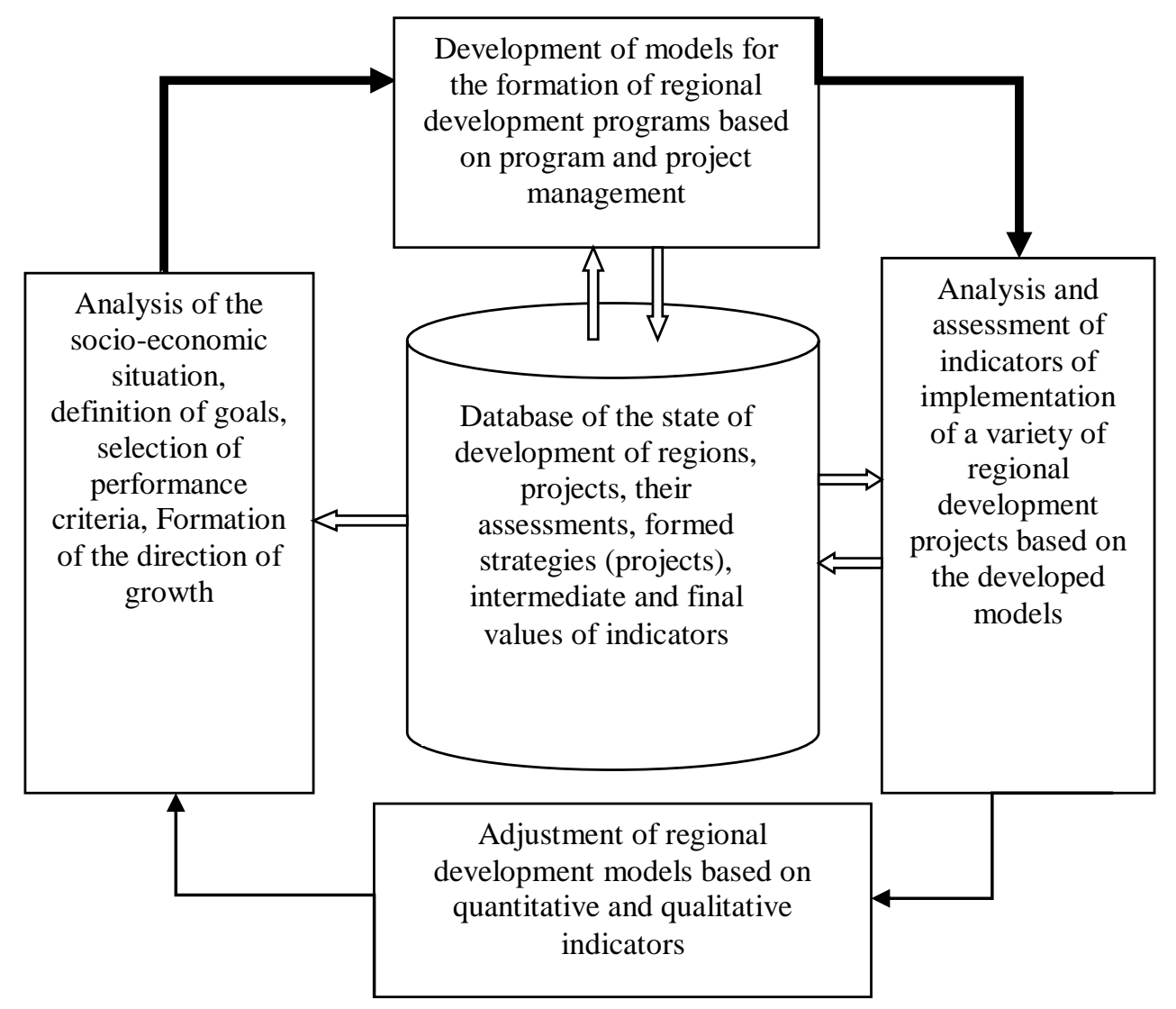

Figure 6. The structure of the life cycle of the analytical system modeling of regional development in DSS Source: authors

The database should contain all indicators of the development of the region and data on the resources of the region: data on the population $\mathbf{L}$, labor productivity $\mathbf{A}$, efficiency and profitability $\boldsymbol{\eta}$, the volume of material production $\mathbf{K}$, the state of scientific research, reflected in the indicators of technological development $\mathbf{W}$, on interregional and between -national economic relations $\mathrm{H}$, according to which the state vector $\mathbf{z}_{\mathbf{t}}$ and $\mathbf{z}_{\mathrm{t}+\mathbf{1}}$ of the control model is formed, according to the formula (2).

A block for analyzing the socio-economic situation, defining goals, choosing efficiency criteria, forming directions of growth. Here $\mathrm{z}_{\mathrm{t}+1}$ control models are formed, according to the formula (4).

According to the formula (5), the region of admissible control actions is determined $\mathbf{U}$ is the product of the sets $\mathbf{U}_{\mathbf{i}}$ for each i-th component of the control vector.

The system of limitations of the model is determined by the formula (6) with the boundaries of the period of consideration $\mathbf{T}$ and $\boldsymbol{\varphi}$ - the vector of resource limitations of development programs.

Regions of growth and management are determined depending on the set of possible management decisions, constraints, management structure, dynamics and using forecasting methods. We have defined innovative development as growth rates, that is, an increase in gross regional product; in these conditions, the management system is aimed at expanding the $\mathbf{P}_{\mathbf{t}}$ growth zone. Control of the development of the system in the "growth zone" is carried out using the vector of output values of the component of the vector yt, this includes the value and structure of regional income $\mathbf{Y}$, elements of regional wealth $\mathbf{N}_{\mathbf{R}}$, and also indicators reflecting the well-being of the population $\mathbf{V}$, determined levels of labor productivity and economic 
efficiency of production, volume and efficiency of foreign trade, etc.

The development of the presented model of the system in the established growth zone $\mathbf{P}_{\mathbf{t}}$ is described by the expression (formula 7). The systemic management model consists of the following 3 equations of growth and constraints (formulas 8-10). The development trajectory functions that allow achieving an increase in GRP have a general form (formula 11). Based on the application of the cybernetic model and development control algorithms, the system model supports the optimal control mode (formula 12). The trajectory of optimal, balanced and proportional growth is characterized by dependencies, according to (formulas 13 and 14).

The block for the development of models for the formation of regional development programs on the basis of program and project management. Here, based on the methodology of a comprehensive assessment of models, programs of innovative development are formed on the basis of a complex of projects in the areas of development.

Block for analysis and evaluation of indicators of the implementation of the set programs-projects for the development of the region according to the developed models. Here, intermediate and final results of the implementation of innovative development programs are formed. There is an analysis and comparison of the results of achieving indicators - criteria for the implementation of projects-programs, the formation of calculated and achieved indicators of the implementation of the development program.

A block for adjusting the regional development models based on taking into account quantitative and qualitative indicators - criteria for ongoing projects. If necessary, adjustments are made based on data from the project indicators database. The proposed mathematical methods and system models of problems of operational management of programs allow taking into account the costs of including and / or excluding projects from the program and reducing the costs of implementing programs and achieving the efficiency of using the allocated financial and time resources.

Let us describe the logical-structural model of the F\&IRIDP decision support system itself based on the modular structure, presented in Figure 7, which shows the Decision support systems (DSS) diagram. DSS focused on F\&IRIDP is based on interaction with all participants in the process of innovative development of regions, and on the analysis of interaction between various program participants. The task of the DSS is to develop optimal strategies (programs consisting of projects), considering the internal reconciliation of models and data. The development and implementation of strategies for integrated management of IDR (target-oriented and program-project approach) in accordance with national legislation and directives (state development programs) is not an easy task. DSS for management allows for different scenarios to compare innovation strategies based on the alignment of several goals.

The objectives of the DSS include: analysis of various model-based management alternatives, communication, and H\&M management. It is important to attract potential users during DSS design. The development of an optimal management strategy should comprehensively provide for the interaction of participants in the innovation process, processes taking place in all directions of development and at different levels, which means collective participation in decision-making.

Responsibilities for the management of the IDR are assigned to the regional administration (as an executive body), in turn, interacting with various departments of the republican and interregional levels. Indicators that are taken into account as decision-making criteria and how they were implemented are presented above. 


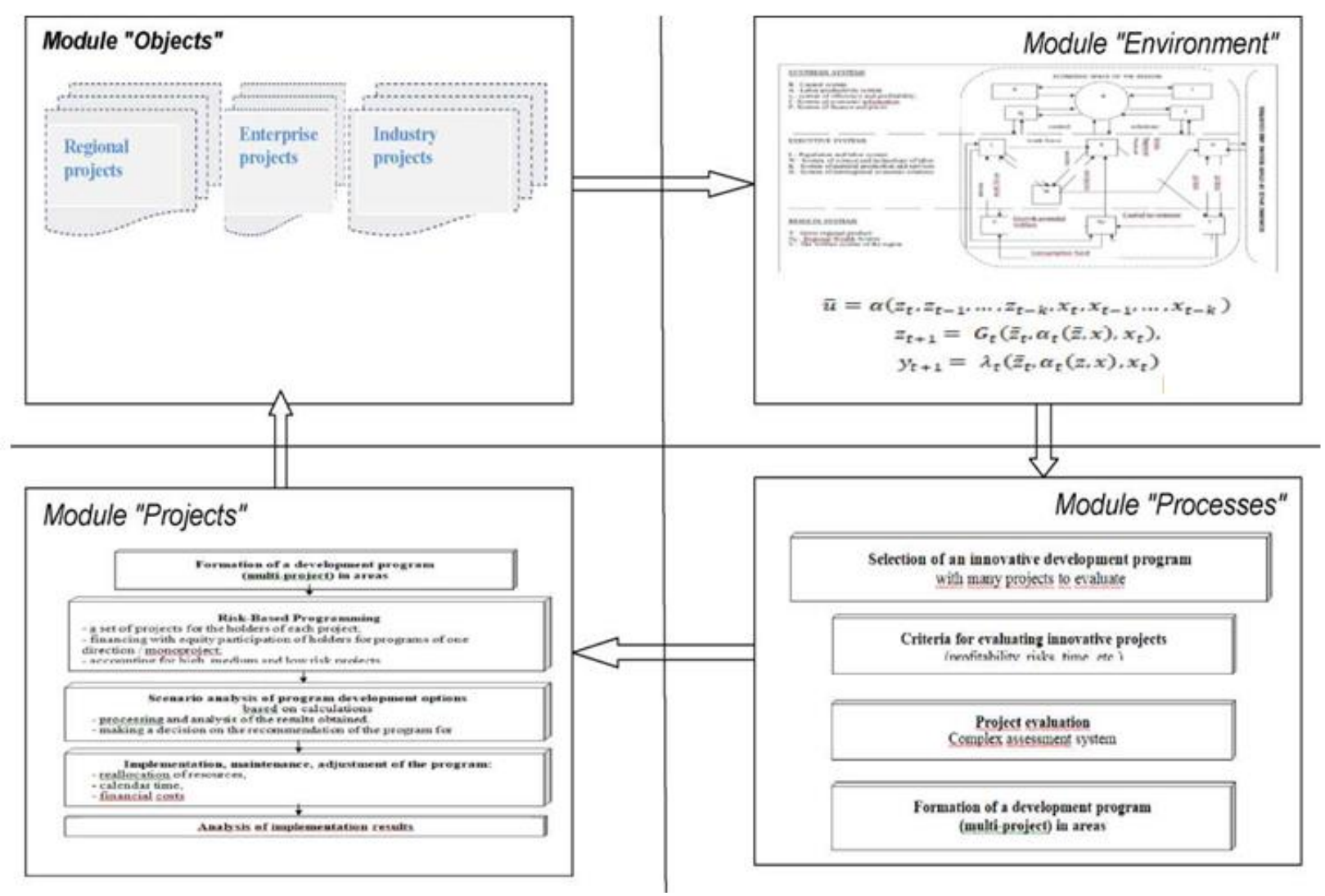

Figure 7. System diagram of the decision support system F\&IRIDP Source: authors

DSS has a multipurpose nature, differences in the purpose and scale of the models and data used, therefore, we will use a modular structure with four functionally interconnected modules related to four subsystems of the economic space (objects, environments, processes, projects) according to NTES. In the module "Environment", the system of the region's resources is analyzed and the direction of movement in the economic space is determined (Figure 6), the calculation of which is made according to the dynamic model (formulas 12-14).

The module "Processes" analyzes the action plan, indicators and indicators of the state program of innovative development, potential projects that will be considered for inclusion in the emerging program of innovative development of the region, indicators-criteria for projects, their expert assessments and priorities are formed. The results of project execution are also transferred here for direct transfer to the program control center. This module also includes a procedure for monitoring the implementation of programs based on the analysis of the implementation of programs and their indicators-criteria. If it is necessary to adjust the programs, the "Projects" module starts working.

In the "Projects" module, projects are directly formed on the basis of the methodology for a comprehensive assessment of the region's innovative development described in the work (you can connect a similar assessment of the industry and the enterprise implementing an innovative project, since projects are formed from multilevel programs). This also includes the issuance of project programs (optimal strategies), analysis and formation of implementation results, development scenarios for transfer to the program control center.

Module "Objects". This includes all objects in the region that implement the developed development project programs. Programs - projects are presented, according to the objects of the region, in the form of projects of three levels: regional, sectoral levels and enterprise levels. Such division is necessary for the efficient allocation 
of financial resources, since each level has its own development program. So, projects at the regional level include programs from the development program, for example, with the following content: "Providing measures of state support aimed at increasing labor productivity" or "Financing projects", for which separate enterprises or industries are allocated funding through the regional administration. In the practice of allocating budget funds, they are allocated as a whole for regional development, and only then are distributed within the region. Such points of the programs should also be formalized in the form of projects and considered in the process of forming programs with their own criteria-indicators, when it is possible to clearly track both the expenditure and the effect of costs.

Thus, the DSS is organically embedded as an information and analytical system with the function of system modeling of the processes of formation and implementation of programs into the general system of transition of the state program of innovative development to program and project management of innovative development of regions.

\section{CONCLUSIONS}

1. A model of economic space for innovative development has been developed according to NTES with variable characteristics of space and time in the form of four systems "objects-environments-processesprojects", in which the corresponding regional subsystems are located. Such a representation in the notations of the new theory of economic systems allows for the transition to project management and the presentation of the structure of the regional economic system in the form of four systems: regional "power-economy-society-business".

2. Based on the analysis of target-oriented management and the new theory of economic systems, where the basis of the four-helix model is projects, it is concluded that it is necessary to supplement it with project management. The concept and methodology of the transition to program-project management in the formation and implementation of programs for innovative development of regions is proposed. Such a transition to program-project management allows, in contrast to the process-based one, on the basis of which program-target management is implemented, to focus on achieving the set goal, and not on the process, as well as flexible management, instead of rigid structures.

3. Based on the presentation of innovative development through NTES in space and time, the development of a cybernetic scheme and the logical structure of the space of the economic system of the region for the management of innovative development through system modeling, the transition to a dynamic economic and cybernetic model with discrete variables was made, the state vector of which gives the position of the system in space at any time and allows to determine the trajectory in the direction of optimal growth.

Thus, we can talk about the following points of novelty, based on the results and conclusions of the presented studies:

1. A model of the economic space of the region's innovative development has been built, based, in contrast to the existing ones, on the notation and principles of the new theory of economic systems. On the basis of this model, the possibility and expediency of the transition from the existing program-target method of management to the program-project management of $R \& D$ is substantiated, which makes it possible to concretize the ways and stages of solving the problems of innovative development. A methodology for such a transition has been developed, which makes it possible to form and implement programs for the innovative development of regions based on system modeling.

2. A systemic dynamic economic-cybernetic model of a region with discrete variables, the state vector of which indicates the position of the system in space and time, has been developed. In contrast to the existing approach, which separately focuses on the development of the innovative sector of the economy 
of the country and regions, such a model is based on a new paradigm of three-vector innovative development, allows us to consider innovative development systematically and quantitatively present goals, criteria for managing the innovative development of regions and the trajectory of optimal growth.

\section{REFERENCES}

Alekseev, S. G. (2009). Assessment of the innovative potential and innovative activity of the regions of the Siberian Federal District. Bulletin of the Buryat State University, 2, 111-117 (in Russian).

Bakhtizin, A. R. and Akinfeeva, E. V. (2010). Comparative assessments of the innovation potential of the regions of the Russian Federation. Problems of forecasting, 3, 73-81 (in Russian).

Doloreux, D. and Parto, S. (2005). Regional innovation systems: current discourse and unresolved issues. Technology in society, 27 (2), 133-153. https://doi.org/10.1016/j.techsoc.2005.01.002

Granberg, A. G. (1989). The economic mechanism of inter-republican and interregional relations. Novosibirsk, Russia: Nauka, 26 p.

Granberg, A. G. (2003). Fundamentals of regional economics. Moscow, Russia: Publishing House of the State University Higher School of Economics, 495 p. (in Russian).

Kitsios, F. and Kamariotou, M. (2018). Decision support systems and strategic information systems planning for strategy implementation. Journal of Decision Support Systems, 3 (1/2), 53-70. http://dx.doi.org/10.1504/IJDSS.2018.094260

Kleiner, G. B. (2007). Systems paradigm and economic policy. Social Science and Modernity, 3, 99-114 (in Russian).

Kleiner, G. B. (2011). Mesoeconomics of development. Moscow, Russia: Nauka, 805 p. (in Russian).

Kleiner, G. B. (2015). State - region - industry - enterprise: framework of systemic stability of the Russian economy. Part 2. Economy of the region, 3, 9-17 (in Russian).

Kleiner, G. B., Shchepetova, S. E., Lapina, M. A., Sirota, E. N., Zvyagin, L. S., Shmerling, D. S., Shcherbakov, G. A., Uandykova, M. K., Zbrishchak, S. G. and Nikitochkina, Yu. V. (2019). Systemic mechanisms of coordination in an innovative economy. Moscow, Russia: Knorus, 270 p. (in Russian).

Krugman, P. (1994). Competitiveness: a dangerous obsession. Foreign Affairs, 73 (2), $28-44$.

Kuznetsov, D. V. (2008). Features of building a regional innovation system. Transport business of Russia, 6, 108-111 (in Russian).

Lau, A.K.W. and Lo, W. (2015). Regional innovation system, absorptive capacity and innovation performance: an empirical study. Technological Forecasting and Social Change, 92, 99-114. https://doi.org/10.1016/j.techfore.2014.11.005

Leontiev, V. (1997). Interbranch economy. Moscow, Russia: Economics, 480 p. (in Russian).

Makarov, V. L. and Bakhtizin, A. R. (2013). Social modeling is a new computer breakthrough (agencyoriented models). Moscow, Russia: Economics, 295 p. (in Russian). 
Manescu, M. (1986). Economic cybernetics. Moscow, Russia: Economics, 318 p. (in Russian).

McGregor, J. A. and Pouw, N. (2017). Towards an economics of well-being. Cambridge Journal of Economics, 41, 1123-1142. https://doi.org/10.1093/cje/bew044

Medvedev, D. A. (2016). Socio-economic development of Russia: the acquisition of new dynamics. Economic Issues, 10, 5-30 (in Russian).

Mensch, G. (2006). If this long wave steps- up and breaks: what then? In: T. C. Devezas (Ed.), Kondratieff Waves, Warfare and World Security (pp. 80-90). Amsterdam, Netherlands: IOS Press.

Minaev, N. N. Eliseev, A. M., Kudyakov, V. A., Ustinova, M. V., Rumina, Yu. A. and Volchkova, I. V. (2008). Organization of a system for monitoring and regulating innovative development of the region: industry aspect. Tomsk, Russia: Publishing house of the Tomsk State University of Architecture and Civil Engineering, 97 p. (in Russian).

Morris, W. (1971). Science of management. Moscow, Russia: Mir, 304 p.

OECD. (2019). The OECD innovation strategy: getting a head start on tomorrow. OECD Publishing, 225 p. https://doi.org/10.1787/9789264083479-en

Padmore, T. (1998). Modeling systems of innovation: an enterprise - centered view. Research Policy, 26, $605-624$.

Polenske, K. R. (2007). The economic geography of innovation. Measurement of the clustering and dispersion of innovation. Cambridge, UK: Cambridge University Press, p. 337 (in Russian).

Polukeeva, A. V. (2014). Indicators of innovative activity of enterprises. Econominfo, 22, 74-77 (in Russian).

Porter, M. (2002). Competition. Moscow, Russia: Williams, 496 p.

Porter, M. E. (2000). Locations, clusters, and company strategy. In: G. Clark, M. Feldman, M. Gertler (Eds.), The Oxford handbook of economic geography (pp. 253-274). Oxford, UK: Oxford University Press.

President of the Russian Federation. (2018). Decree of the President of the Russian Federation of May 7 , 2018 No. 204 "On the national goals and strategic objectives of the development of the Russian Federation for the period up to 2024". Retrieved from http://publication.pravo.gov.ru/Document/View/0001201805070038

Rothwell, R. (1994). Towards the fifth-generation innovation process. International Marketing Review, 11 (1), 7-31. https://doi.org/10.1108/02651339410057491

Rycroft, R. W. and Kash, D. E. (2002). Path dependence in the innovation of complex technologies. Technology Analysis \& Strategic Management, $14 \quad$ (1), 21-35. http://dx.doi.org/10.1080/09537320220125865

Shash, N. N. (2014). Problems of transition to the program budget: new challenges to the budgetary policy of Russia. Accounting in budgetary and non-profit organizations, 11, 31-38 (in Russian). 
Tödtling, F. and Trippl, M. (2005). One size fits all? Towards a differentiated regional innovation policy approach, Research Policy, 34, 1203-1219.

United Nations. (2015). Millennium development goals: 2015 Report. Retrieved from https://www.un.org/en/development/desa/publications/mdg-report-2015.html

Verganti, R. (2008). Design, meanings, and radical innovation: a metamodel and a research agenda. Journal of Product Innovation Management, 25 (5), 436-456. https://doi.org/10.1111/j.15405885.2008.00313.x

Wahyudin, A. and Hasibuan, Z. A. (2015). Research classification in strategic information system planning: a critical review. In: International Conference on Science in Information Technology, ICSITech, Yogyakarta, Indonesia, October 27-28, 2015 (pp. 287-292). IEEE. https://doi.org/10.1109/ICSITech.2015.7407819

Webster, J. (2002). Analyzing the past to prepare for the future: writing a literature review. MIS Quarterly, $26,13-23$.

Yang, J., Pita, Z. and Singh, M. (2013). Conceptual framework for assessing strategic information systems planning (SISP) success in the current dynamic environments. In: Proceedings of 24th Australasian Conference on Information Systems (ACIS), Melbourne, Australia, December 4-6, 2013, pp. 1-10 (in Russian).

Zviran, M. (1990). ISSPSS: a decision support system for information systems strategic planning. Information \& management, 5 (19), 345-359. 